\title{
ISOLATION AND IDENTIFICATION OF SOME SHORT CESTODES INFECTING GREATER FLAMINGO (PHOENICOPTERUS RUBER ROSEUS) AT GIZA ZOO, EGYPT
}

\author{
A.M.I. Abd El Aal and F.A.I. Oraby. \\ Animal Health Research Institute, Agricultural Research Center, \\ Dokki, Giza, Egypt. (Matrouh branch)
}

\begin{abstract}
Investigation of the gastrointestinal tract of fifteen greater flamingo (Phoenicopterus ruber roseus) at Giza Zoo, Egypt revealed that it was infected with five species of short cestodes belonging to three families of order Cyclophyllidea (two spp. Belonging to F.Hymenolepididae, two spp. Belonging to F.Progynotaeniidae and one sp. belonging to F. Metadilepididae). The recoverd Hymenolepidean cestoda were Sobolevicanthus gracilis and Cladogynia phoeniconaiadis with prevalence rate $20 \%$ for each while the detected Progynotaeniidean cestoda were Gynandrotaenia stammeri and Leptotaenia ischnorhyncha with infection rate $13.3 \%$ for each. Meanwhile, the only recorded Metadilepidean cestode was Yapolepis sp. with prevalence 26.7\%. The morphological features of those cestodes were discused. This study provides the first record of S. gracilis, G. stammeri, L. ischnorhyncha and Yapolepis sp. In Giza Zoo, Egypt.
\end{abstract}




\section{INTRODUCTION}

Wild birds play an important role in our life because they act as a host and disseminator for many ectoparasites, endoparasites, bacterial and viral diseases which affect both human and domestic birds. The diet of aquatic wild birds usually contains arthropods, earth worms, fish and crustaceans, many of those are intermediate hosts for helminthes. Therfore, aquatic wild birds are expected to carry high parasitic burden. Flamingo as a wild aquatic bird require a diet reach in brine shrimps Artemia parthenogenetica (crustacea) to give their plumage pink, whithout it their feathers turn whight. Those brine shrimps are intermediate hosts for several cestodes whose final hosts are water birds Sànchez et al., (2007). Therfore, Flamingos (Phoenicopterus ruber roseus) have a high risk of infection with those cestodes. In Egypt, the parasitic fauna of Flamingos are not previously studied, except what done by Oraby (1993). So, more research studies are needed to cover this shortage. The present study aimed to evaluate the prevalence and description of short cestodes infecting Flamingos at Giza Zoo, to aid in mapping of parasitic fauna of flamingos at Egypt.

\section{MATERIALS AND METHODS}

A total of 15 freshly dead greater flamingos (Phoenicopterus ruber roseus) were collected sporadically from Giza Zoo, Egypt. Greater flamingo was identified according to El-houssini (1954), Brown et al., (1982) and Cerny (1987). After dissection of each bird, the gastrointestinal tract washed with normal saline $(0.9 \% \mathrm{Na} \mathrm{cl})$ and sedimented. The sediment was examined by steriodissecting microscope for collection of cestodes. The isolated cestodes were washed in normal saline and mounted for examination according to Kruse and Pritchard (1982), Beaver et al., (1984) and Schmidt (1992). The specimens were identified according Yamaguti (1959) and Khalil et al., (1994). 


\section{RESULTS}

Parasitological examination revealed that greater flamingo was found to be infected with five short cestodes belonging to three families of order Cyclophyllidea; two spp. of F. Hymenolepididae, two spp. of F.Progynotaeniidae and one sp.of F. Metadilepididae. The Hymenolepidean cestodes were Sobolevicanthus gracilis and Cladogynia phoeniconaiadis with prevalence rate $20 \%$ for each while Progynotaeniidean cestodes were identified as Gynandrotaenia stammeri and Leptotaenia ischnorhyncha with infection rate $13.3 \%$ for each. Meanwhile, the only recorded Metadil-epidean cestode was Yapolepis sp. with prevalence rate $26.7 \%$, table (1).

Table (1): Prevalence of short cestodes recovered from greater flamingo (Phoenicopterus ruber roseus) collected at Giza Zoo.

\begin{tabular}{||l||c||c||c||}
\hline \multicolumn{1}{|c||}{ Short cestodes } & $\begin{array}{c}\text { No. of } \\
\text { ex. bird }\end{array}$ & $\begin{array}{c}\text { No. } \\
\text { infected }\end{array}$ & $\begin{array}{c}\text { Prevalence } \\
\text { \% }\end{array}$ \\
\hline \hline 1-Sobolevicanthus gracilis & 15 & 3 & 20 \\
\hline 2-Cladogynia phoeniconaiadis & 15 & 3 & 20 \\
\hline 3-Gynandrotaenia stammeri & 15 & 2 & 13.3 \\
\hline 4-Leptotaenia ischnorhyncha & 15 & 2 & 13.3 \\
\hline 5-Yapolepis sp. & 15 & 4 & 26.7 \\
\hline
\end{tabular}

The morphological description of recorded cestodes was illusterated as follows:

1- Order: Cyclophyllidea Van Beneden in Braun, 1900

Family: Hymenolepididae Ariola, 1899.

Genus: Sobolevicanthus Spasskii and Spasskaya, 1954.

Species: Sobolevicanthus gracilis Spasskii and Spasskaya, 1954 (Fig. 1-6).

Site of infection: intestine. 
The worm was small cestode with up to 21 proglottids. The whole body length measured $1.06-1.12 \mathrm{~mm}$. in length by $0.20-0.22 \mathrm{~mm}$. width. The scolex measured $0.08-0.11 \mathrm{~mm}$. length (with non protruded rostellum) by $0.14 \mathrm{~mm}$. width. It was of retractable rostellum, armed with sigle crowen of eight hooks and four unarmed suckers. Proglottids were broader than long, craspedote. The mature ones measured 0.20-0.22 mm. wide by 0.04-0.05 mm. long. While the gravid ones had nearly squarish appearance and measured $0.09-0.22 \mathrm{~mm}$. wide by $0.07-0.10 \mathrm{~mm}$. long. Reproductive organs per proglottid were single consisting of three rounded, smooth testes arranged in triangle manner, while ovary was lobed, median and ventral to testes. External and internal seminal vesicles present. Vitellarium was compact, median and dorsally postovarian. Uterus was saccular. Genital pores were unilateral.

2- Order: Cyclophyllidea Van Beneden in Braun, 1900.

Family: Hymenolepididae Ariola, 1899.

Genus: Cladogynia Baer, 1938.

Species: Cladogynia phoeniconaiadis Baer, 1937 (Fig., 7-10)

Site of infection: intestine.

It was a medium sized short cestode. The scolex measured 0.26$0.28 \mathrm{~mm}$. in length and $0.28-0.29 \mathrm{~mm}$. width and consisted of retractable rostellum, with sigle crowen of eight hooks and four unarmed suckers. Proglottids were distinctly craspedote. The mature ones measured 0.21 $0.24 \mathrm{~mm}$. width by 0.07-0.09 $\mathrm{mm}$. long. Testes were three, rounded, arranged in row and situated in medulla. Ovary was lobed, median and ventral to testes. Vitellarium was compact and postovarian. Seminal receptacle was well developed. Uterus was reticular. 
3- Order: Cyclophyllidea Van Beneden in Braun, 1900.

Family: Progynotaeniidae Fuhrmann, 1936.

Genus: Gynandrotaenia Fuhrmann, 1936.

Species: Gynandrotaenia stammeri Fuhrmann, 1936 (Fig., 11).

Site of infection: intestine.

It was a small cestode with 4-9 proglottids, First proglottid behind scolex was female $(0.16-0.22 \mathrm{~mm}$. in width and $0.15-0.24 \mathrm{~mm}$. in length) and the next was male $(0.17-0.18 \mathrm{~mm}$. in width and $0.13-0.18 \mathrm{~mm}$. in length) with regular alteration which was a characteristic feature for this family. The total body length of worm measured $0.63-1.26 \mathrm{~mm}$. by 0.17 0.21 width. Scolex was comparatively large and measured $0.25-0.39 \mathrm{~mm}$. length by $0.17-0.20 \mathrm{~mm}$. width. Proscolex was dome-shaped, retractable within metascolex. Rostellum was retractable with a single crown of six hooks. Male genital pores open laterally near posterior margin of proglottid, alternating regularly in successive male proglottids. Testes were numerous. Ovary was lobed, occupying most of medulla. Vitellarium was compact, transversaly elongate near posterior margin of proglottid. Uterus was a median longitudinal duct, becomig sac-like when changed to gravid.

4- Order: Cyclophyllidea Van Beneden in Braun, 1900.

Family: Progynotaeniidae Fuhrmann, 1936.

Genus: Leptotaenia Cohn, 1901.

Species: Leptotaenia ischnorhyncha Lühe, 1936 (Fig., 12-14).

Site of infection: intestine. 
It was a small cestode and measured $1.44 \mathrm{~mm}$. long by $0.33 \mathrm{~mm}$. width. The strobila wedged-shape and consisted of 13 proglottids having a characteristic regular alteration of female and male proglottids . Scolex was comparatively large and measured $0.33 \mathrm{~mm}$. in length and $0.30 \mathrm{~mm}$. in width. Rostellum retractable with a single crown of hooks. Cirus was large and armed. Ovary was bilobed and large. Vitellarium was compact and postovarian. Uterus was saccular and filling whole of medulla. Male genitalia was completely developed in posterior proglottids only.

5- Order: Cyclophyllidea Van Beneden in Braun, 1900.

Family: Metadilepididae Spasskii, 1909.

Genus: Yapolepis Mariaux, 1991.

Species: Yapolepis sp. (Fig., 15-17).

Site of infection: intestine.

The worm was a small cestode with 18-20 proglottids. The total body length was $0.91-0.98 \mathrm{~mm}$. and $0.16-0.22 \mathrm{~mm}$. in width. The scolex measured $0.19 \mathrm{~mm}$. in length and $0.15 \mathrm{~mm}$. in width and consisted of unarmed sucker-like rostellum without saccular sheath and four unarmed suckers. Proglottids were craspedote and wider than long. The mature ones measured 0.15-0.22 mm. in width and 0.04-0.06 mm. long and toward gravide ones had nearly squarish appearance and measured 0.10$0.12 \mathrm{~mm}$. in width and 0.06-0.08 $\mathrm{mm}$. long. Genital pores unilateral. Genital organs single per proglottid, where testes dorsal to ovary in one field. Cirrs sac pyriform, thick walled reaching middle of proglottid. Vitellarium was compact, medium and near posterior margine of proglottid. Uterus saccular and in median field. 

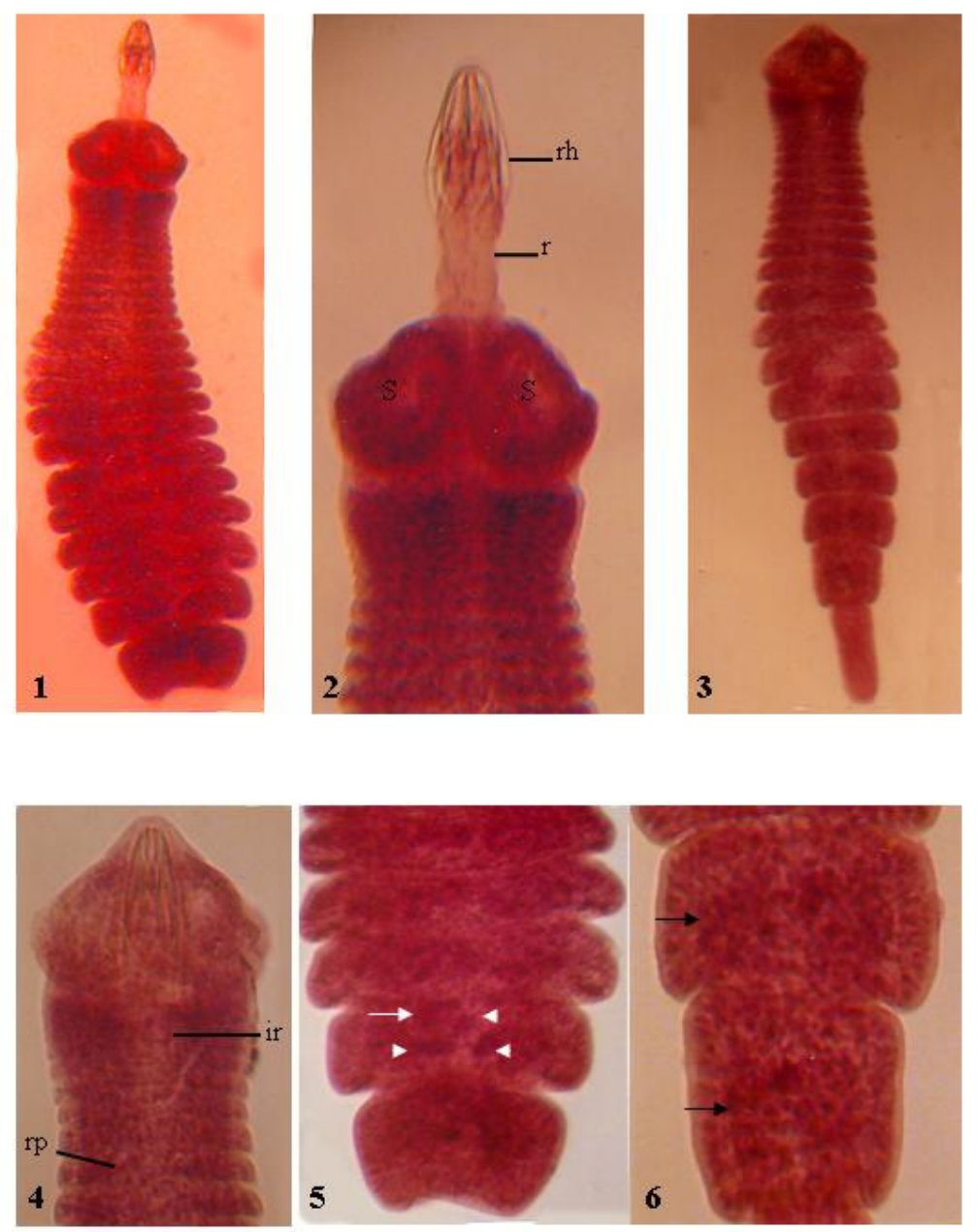

Figs. (1-6): Sobolevicanthus gracilis; 1- Entire worm showing protruded rostellum $\mathrm{x} 4,2$ - Scolex showing rostellum (r), rostellum hooks (rh), suckers (s) $x 10,3$ - Entire worm with non protruded rostellum $x 4,4$ - Scolex showing invaginated rostellum (ir) and rostellum poush (rp) x10, 5- Mature proglottids showing three testes (white arrow head), Ovary (white arrow) x10, 6- Gravide proglottids showing gravide uterus (black arrow) x10.

Kafrelsheikh Vet. Med. J. Vol. 7 No. 1 (2009) 

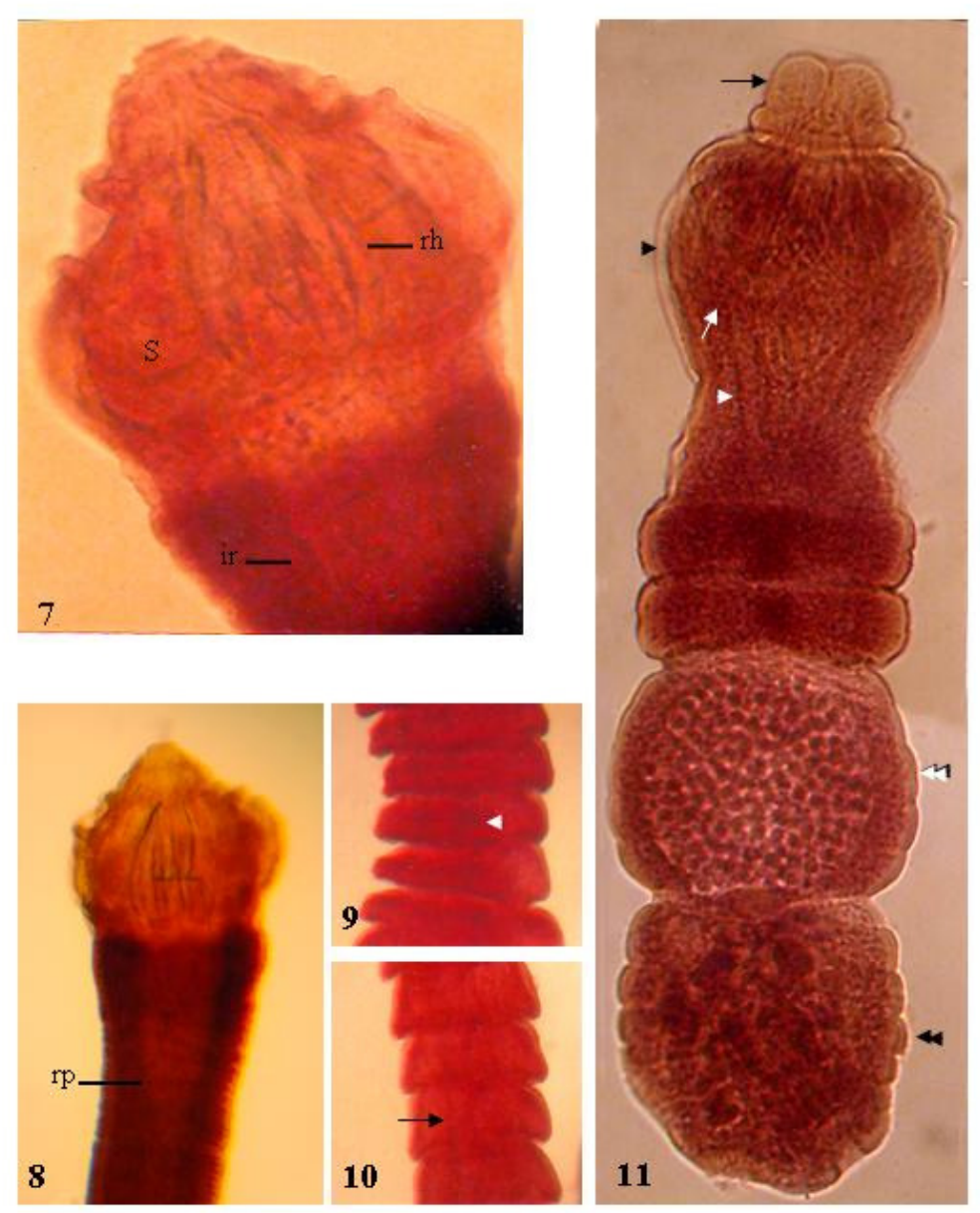

Figs. (7-10): Cladogynia phoeniconaiadis; 7- Scolex showing invaginated rostellum (ir), rostellum hooks (rh), suckers (s) x10, 8- Scolex showing rostellum poush (rp) x5, 9- Mature proglottids showing testes (white arrow head) $x 10,10$-Gravide proglottids showing gravide uterus (black arrow) x10.

Fig. (11) Gynandrotaenia stammer; showing proscolex (black arrow), metascolex (black arrow head), suckers (white arrow), rostellum poush (white arrow head), male proglottid (double white arrow head) and female proglottid (double black arrow head) x10.

Kafrelsheikh Vet. Med. J. Vol. 7 No. 1 (2009) 

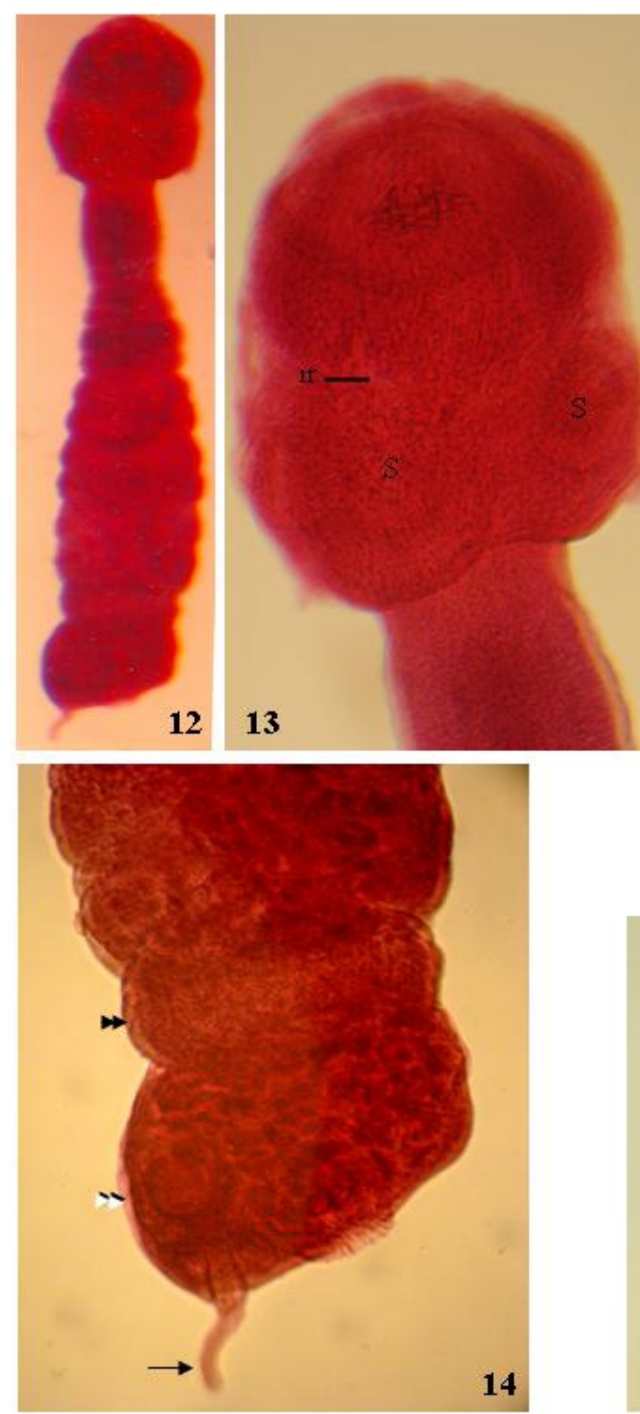
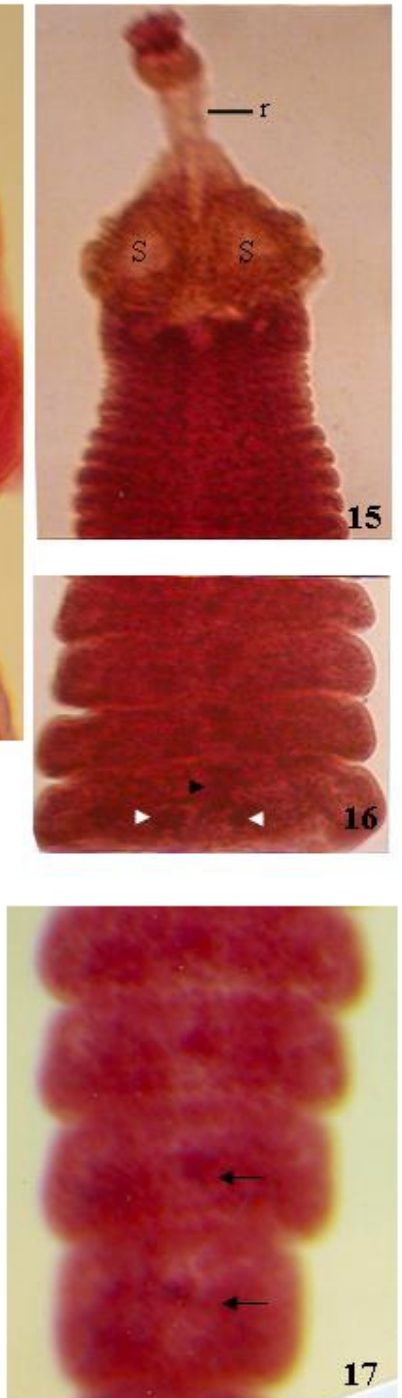

Figs. (12-14): Leptotaenia ischnorhyncha; 12- Entire worm $\times 2.5,13-$ Scolex showing invaginated rostellum (ir) and suckers (s) x4, 14- Posterior end of worm showing female proglottid (double black arrow head) and male proglottid (double white arrow head) with cirrus (black arrow) x10.

Figs. (15-17) Yapolepis sp.; 15- Scolex showing protruded rostellum (r) and suckers (s), 16- Mature proglottids showing testes (white arrow head), ovary (black arrowhead), 17- Gravide proglottids showing gravide uterus (black arrow) $\mathrm{x} 10$. 


\section{DISCUSSION}

Cestodes of five species of three families belonging to order Cyclophyllidea were recovered, identified and morphologically studied from greater flamingo aiding in mapping of parasite infection for this kind of aquatic birds at Giza Zoo, Egypt. The occurance of this large number of cestodes greater flamingo is attributed to its high need to diet rich in brine shrimps which contain cysticercoids of many Cyclphyllidean cestodes of aquatic birds Georgiev et al., (2005), Snàchez et al., (2006) and Snàchez et al., (2007).

Sobolevicanthus gracilis was isolated from greater flamingos with infection rate $20 \%$ as a new host record for the parasite at Giza Zoo, Egypt, while Canaris et al., (1981) and Farias and Canaris (1986) found it as a new host record in Green-winged teal and Mexican duck with prevalence rate $23 \%$ and $10.8 \%$ respectively. The morphological description of $\boldsymbol{S}$. gracilis agreed with that illusterated by Spasskii and Spasskaya (1954).

In regard to $\boldsymbol{C}$. phoeniconaiadis coincident with that described by Baer (1937) except for the absence of pseudoscolex and microtriches from posterior surface of proglottids.

The recovered Progynotaeniidean cestodes; G. stammeri and $\boldsymbol{L}$. ischnorhyncha have the same habitate and all morphological features with characteristic regular alteration of female and male proglottids as described by Fuhrmann (1936). 
Finally, Yapolepis sp. Characterized by having unarmed sucker-like rostellum without saccular sheath in agreement with Mariaux (1991), but its habitate was in greater flamingos (aquatic birds) disagreeing with Spassakii (1959) who mentioned that this worm present in non aquatic birds. This difference may attributed to resident life of greater flamingos in Giza Zoo, leading adaptation of the parasite to infect aquatic birds or may be accidental pathway.

This study provides the first host records of S. gracilis, G. stammeri, L. ischnorhyncha and Yapolepis sp. in greater flamingos at Giza Zoo, Egypt.

\section{ACKNOWLEDGEMENT}

The authors gratefully acknowledge Dr. Mahmoud A. EL-Seify Professor of Parasitology, Vet. Med. KafrelSheikh Univeristy, Egypt for his valuable help, encouragement and facilities he gives in this study.

\section{REFERENCES}

- Baer, J.G. (1937) : Un genre de cestodes d' oiseaux. Bulletin de la Société Neuchâteloise des Sciences Naturelles 62, 149-156.

- Beaver,K. C.; Jun, R.C. and Cupp, E.W. (1984): Clinical parasitology, USA, Lea Febiger,Philadelphia.

- Brown,L.H.;Urban,E.K.and Newman,K. (1982): The birds of Africa Vol. 1, Academic press, Inc. (London) LTD.

- Canaris,A.G.;Mena,A.C.and Bristol,J.R. (1981): Parasites of waterfowel from southwest Texas: III. The Green-Winged Teal, Anas crecca. J. of wildlife diseases 17(1): 57-64. 
- Cerny, W. (1987): A field guide in colour to birds. Octopus Book Limited. 59 Grosvenor street, London, WI.

- El houssini, M.H. (1954): Birds of egypt. Arabic text, $2^{\text {nd }}$. Ed. Anglo Egyptian Library, Cairo.

- Farias, J.D. and Canaris, A.G. (1986): Gastrointestinal helminths of the mexican duck, Anas platyrhynchos diazi ridgway, from North United States. J. of wildlife diseases 22(1): 51-54.

- Fuhrmann, O. (1936): Gynandrotaenia stammeri n. g. n. sp. Revue Suisse de Zoologie 43, 517-518.

- Georgiev, B.B.; Snàchez, M.I.; Green, A.G.; Nikolov, P.N.; Vasileva, G.P. and Mavrodieva, R.S. (2005): Cestodes from Artemia parthenogenetica (Crustacea, Branchiopoda) in the Odiel Marshes, Spain: Asystematic survey of cysticercoids. Acta Parasitologica 50(2): 105117.

- Khalil, L.F., Jones, A. and Bray, R.A. (1994): Keys to the cestode parasites of vertebrates. CAB International, Wallingford, Oxon, UK.

- Kruse, G.O.W. and Pritchard, M.H. (1982): The collection and presservation of animal parasites. Univ. of Nebraska press, USA.

- Mariaux,J.(1991): cestodes of birds from the Ivory Coast. Yapolepis yapolepis n.g.,n.sp.a new metadilepidid(Cyclophyllidea: Paruterinoidea) parasite of the icterine greenbul (Aves: Pycnonotidae). Systematic Parasitology 18, 187-191. 
- Oraby, F.A.I. (1993): Intensive studies on the cases of deaths among birds of Giza Zoo with special reference to parasitic diseases. Ph.D.V.Sc. Thesis, Fac.of Vet. Med. Cairo Univ

- Schmidt, G.D. (1992): Essentials of parasitology. $5^{\text {th }}$ Ed., Brown, C. Publishers, USA.

- Snàchez, M.I.; Georgiev, B.B.; Nikolov, P.N.; Vasileva, G.P. and Green, A.G. (2006): Red and transparent brine shrimps Artemia parthenogenetica : a comparative study of their cestode infections. Parasitol Res., 100: 111-114.

- Snàchez, M.I.; Georgiev, B.B. and Green, A.G. (2007): Avian cestodes affect the behaviour of their intermediate host Artemia parthenogenetica: An experimental study. Behavioural Processes, 74: 293-299.

- Spasskii,A.A.and Spasskaya,L.P.(1954): Construction of a classification of hyminolepidids parasitic in birds. Trudy Gelmintolo-gicbeskoi Laboratorii 7, 55-119.

- Spassakii, A.A. (1959): A more precise definition of the types of relative positions of the genitalia in hymenolepidids. Zoologicbes-kii Zburnal $38,31-37$.

- Yamaguti, S. (1959): Systema helminthum. Vol. II. The Cestodes of vertebrates. Interscience Publ., New York. 


\section{عزل وتصنيف بعض الديدان الشريطية القصيرة التي تصيب البشاروش بعديقة الحيوان بالجيزة ـ مصر}

$$
\text { أحمد محد إبر/هيم عبد العال - فتحي على إبراهيم عرابي }
$$

معهل بحوث صحة الحيوان - مركز البحوث الزراعية - الاقي - جيزة - مصر (فرع مرسى مطروح)

نتيجة فحص الجهاز الهضمي لعدد 15 طائر من البشاروش من حديقة الحيوان بالجيزة بمصر

تبين إصابتها بخمسة أنواع من الديدان الثريطية القصيرة نتمي إلى ثلاثة عائلات من رتبة السيكلوفيليدى، حيث تم عزل نوعان من الديدان الشريطية القصيرة من كلا من عائلة هيمينوليبديدى و عائلة بروجينو تينيدى ونو عاً واحداً من عائلة ميتا داى ليبديدى. لئ.

الديدان الثريطية المنتمية لعائلة هيمينوليبديدى هي سوبوليفيكانس جر اسيلس، كلادوجونيا فيونى كنيادس بمعدل إصابة 20\% لكلاً منها. بينما المنتمية لعائلة بروجينوتنينيدى كانت جيناندروتينيا ستاميرى ، لبتوتينيا إسكينورينكا بمعدل إصابة 13.3\% لكلاً منها. في حين كانت الدودة الثريطية الوحيدة المسجلة لعائلة ميتا داى ليبديدى هي يابولبس سبيسش بمعدل إصابة 26.7\% . وقد تم توضيح الوصف المورفولوجى لهذه الديدان الثريطبة. تعتبر هذه الدراسة الأولى الني يتم فيها تسجيل الأنواع الآتية؛ سوبوليفيكانس جر اسيلس، جيناندروتينيا ستاميرى، لبتوتينيا إسكينورينكا و يابولبس سبيسش بحديقة حيوان الجيزة بمصر . 